\title{
Physicochemical properties of Saeilmi (Oryza sativa Linne) germinated with different steeping and germination time
}

\author{
Beom-Gyun Jeong, Kap-Seong Choi, Jiyeon Chun* \\ Department of Food Science and Technology, Sunchon National University, Suncheon 57922, Korea
}

\section{침지 및 발아 시간에 따른 발아 새일미의 이화학적 품질 특성}

\author{
정범균·최갑성 · 천지연* \\ 순천대학교 식품공학과
}

\begin{abstract}
This study aimed to investigate the germination characteristics of Saeilmi unhulled rice affected by different steeping $\left(\right.$ at $35^{\circ} \mathrm{C}$ ) and germination $\left(\right.$ at $30^{\circ} \mathrm{C}$ ) time. At first, the 24 h-germinated unhulled rice (GUR) were prepared by germination for $24 \mathrm{~h}$ after steeping for 8, 16, and $24 \mathrm{~h}$. Next, the $24 \mathrm{~h}$-steeped GURs were obtained by germination for 20, 24, 28, and $32 \mathrm{~h}$ after steeping for $24 \mathrm{~h}$. Sprout lengths of GUR were more evenly distributed as steeping and germination time increased. Among $24 \mathrm{~h}$-GURs, the thiamin, niacin, and GABA contents were the highest in 8 h-steeped GUR while the folate content was the highest in 24 h-steeped one. For 24 h-steeped GURs, their levels varied with germination time: the highest contents were observed in 24 h-GUR for the thiamin and the niacin contents (534.6 and 1,281.5 $\mu \mathrm{g} / 100 \mathrm{~g})$, in $32 \mathrm{~h}$-GUR for folate $(58.93 \mu \mathrm{g} / 100 \mathrm{~g})$, and in $20 \mathrm{~h}$-GUR for GABA $(16.3 \mathrm{mg} / 100 \mathrm{~g})$. The glucose content of GUR increased upto 7 times depending on the steeping and germination time: the highest level was observed in $20 \mathrm{~h}$-GUR after $24 \mathrm{~h}$-steeping. ${ }^{\circ}$ Brix of saccharified solution prepared from GURs increased with germination time: the highest was observed in $28 \mathrm{~h}$-GUR after 24-steeping. These results suggest that nutritional, functional, and saccharification properties of rice could be effectively improved by germination, especially with steeping for $24 \mathrm{~h}$ at $35^{\circ} \mathrm{C}$ coupled with germination for $24 \mathrm{~h}$ at $30^{\circ} \mathrm{C}$.
\end{abstract}

Key words : steeping, germination, rice, water-soluble vitamin, GABA

\section{서 론}

국내에서 재배되고 널리 소비되고 있는 자포니카 (Japonica) 쌀은 아밀로오스 함량이 낮고 아밀로펙틴 함량 이 높아서 찰기(sticky)가 높고 강도가 낮아 취반용이나 떡 제조용으로 적합하여 다양한 가공식품으로의 개발이 제한 되어 왔다(1,2). 최근 바쁜 현대인의 생활 패턴으로 밥보다 는 빵이나 면 등과 같은 밀로 만든 간편식 섭취가 증가하면 서 국내산 쌀 소비량은 1 인당 2006년 $78.8 \mathrm{~kg}$ 에서 2017년에

*Corresponding author. E-mail : cjyfall@sunchon.ac.kr Phone : 82-61-750-3258, Fax : 82-61-750-3208

Received 28 May 2018; Revised 2 June 2018; Accepted 22 June 2018.

Copyright (c) The Korean Society of Food Preservation. All rights reserved.
는 $61.8 \mathrm{~kg}$ 으로 지속적으로 감소하면서 국내 쌀 재고량이 증가하고 있다(3). 쌀 소비 촉진을 위하여 전통 쌀 발효 음료(4), 당화 쌀죽(5), 홍국쌀 식혜(6), 편의식 밥류(7) 등 다양한 쌀 활용 가공제품 출시를 위한 연구가 활발하게 진행되고 있다. 다양한 쌀 가공품 개발 노력으로 인하여 2011년 이후 약 쌀 60만 톤이 가공으로 지속적으로 소비되 고 있으며(8), 2016년 식료품 제조로 소비된 쌀은 전년도 대비 $14.5 \%$ 가 증가한 약 70 만 톤 수준에 이르게 되었다. 한편, 주류 산업에서 쌀은 주로 탁주 제조에 이용되어 왔으 나 최근 micro-brewery 맥주 제조 시 맥아를 대체하여 쌀을 활용하는 연구(9)가 시도되면서 맥주 산업에서도 쌀 소비가 점차 확대될 것으로 보인다. 국내산 쌀을 맥주 제조에 이용 시 수입산 보리나 맥아에 비하여 가격이 상대적으로 저렴하 고, 맥주에 부드러운 풍미를 부여할 수 있는 것으로 알려져 있어서 쌀의 맥주 제조로의 활용도가 확대될 수 있을 것으 
로 평가되지만 맥아를 대체할 목적으로 맥주 제조에 이용 시 요구되는 쌀의 당화력이나 기타 영양성 및 기능성에 관한 특성 연구는 아직 미흡한 실정이며, 특히 주로 취반용 으로 소비된 자포니카 쌀에 관한 가공 특성에 관한 연구는 매우 미흡한 실정이다.

곡류는 발아 시 소화율이 높아지고, 생리적 활성이 증대 되는 것으로 알려져 있다. 이는 발아 과정 중 수분을 흡수하 면서 종피가 부풀어 올라 수분과 가스의 투과로 종자 내의 효소들이 활성화되면서 자엽내의 영양성분이 분해되고, 발 아에 필요한 새로운 물질이 합성되어 유용한 생리활성 물질 이 증가하는 것으로 알려져 있다 $(10,11)$. 곡류의 발아는 이 러한 유용 성분들의 증가 외에도 발아 중 당화에 관여하는 hydrolytic enzyme 생성으로 인하여 곡류의 가공 적성 및 효소력이 개선되는 것으로 알려져 있어서 가공 목적에 따라 적절한 발아 조건을 적용한 발아벼 제조가 가능할 것으로 보여진다. 특히, 발아벼는 맥주 제조 시 당화 공정에서 탄수 화물원으로 당을 제공하는 목적 외에도 당화에 필요한 효소 를 함께 제공할 수 있으므로 현재 국내 맥주 제조를 위해 전량 수입되고 있는 맥아를 일부 대체할 수 있을 것으로 기대되는 바, 국산 쌀의 발아 특성 연구를 통한 발아벼 제조 는 맥주 산업의 원료 국산화율을 높이기 위해 선행되어야 할 과정이다.

따라서, 본 연구에서는 국내산 자포니카 품종의 하나인 새일미를 다양한 침지 및 발아 조건에서 영양성분, 기능성 성분, 및 당화 특성 등을 포함한 발아벼의 품질 특성을 조사 하여 국내산 쌀의 micro-brewery 맥주 제조 산업으로의 활 용을 위한 기초자료를 제공하고자 한다.

\section{재료 및 방법}

\section{실험 재료 및 시약}

본 실험에 사용한 벼 품종은 전남 신안의 농가(2015년산) 에서 친환경농법으로 재배한 새일미(saeillmi, SI)를 구입하 여 발아 전까지 $4^{\circ} \mathrm{C}$ 냉장 조건에서 밀폐용기에 보관하며 사용하였다. 발아벼의 특성 연구에 사용된 thiamine hydrochloride, nicotinic acid, nicotinamide, folic acid, $\gamma$ -aminobutyric acid(GABA), gallic acid, L-ascorbic acid, Folin-Ciocalteu's phenol reagent와 1,1-diphenyl-2-picrylhydrazyl (DPPH)은 Sigma-Aldrich(St. Louis, MO, USA)에서 구입하 여 사용하였으며, potassium ferricyanide, trichloroacetic acid 및 ferric chloride는 Wako사(Osaka, Japan)에서 구입하였다. 기타 사용된 시약은 특급 및 HPLC 등급을 사용하였으며, 3 차 증류수는 water purification system(Aqua MaxMT-Ultra, Young Lin Instrument Co., Anyang, Korea)으로 정제된 물을 사용하였다.

\section{벼 발아}

침지시간에 따른 발아 특성 조사를 위하여 새일미 벼에 벼 중량 2 배의 물을 가하여 $35^{\circ} \mathrm{C}$ 에서 $8,16,24$ 시간 동안 각각 침지시킨 후 $30^{\circ} \mathrm{C}$ 에서 상대습도 $90 \%$ 로 조절된 plant growth chamber(DS-52G4P, Dasol, Hwaseong, Korea)에서 24 시간 동안 발아시켰다. 침지 기간 동안 8 시간마다 물을 교환하였으며, 발아 기간 동안은 물을 주기적으로 공급하 였다. 발아된 벼(germinated unhulled rice)는 chamber에서 꺼낸 후 $50^{\circ} \mathrm{C}$ drying oven에서 수분함량이 $15 \%$ 이하가 될 때까지 건조하여 disc mill(BM-D-100, McCoy corporation, Seoul, Korea)을 이용하여 분쇄한 다음 $-70^{\circ} \mathrm{C}$ 에서 보관하여 분석 시료로 사용하였다.

다음으로, 발아 시간에 따른 특성 변화 조사를 위하여 동일한 조건 $\left(35^{\circ} \mathrm{C}, 24 \mathrm{~h}\right)$ 에서 침지시킨 후 $30^{\circ} \mathrm{C}$ 에서 상대습 도 $90 \%$ 로 조절된 plant growth chamber에서 $20,24,28,32$ 시 간 동안 발아시켰다. 이후 건조, 분쇄 및 보관 방법은 이전과 동일하게 처리하였다.

\section{발아율 및 초엽장 분포}

벼의 발아율은 시료의 표본 집단인 벼 낟알 100 개를 기준 으로 전체 벼에서 싹이 출아된 낟알 수를 계수하여 다음과 같이 발아율을 계산하였고, 초엽장 길이는 출아된 벼의 싹 의 길이를 최소 측정단위가 $\mathrm{mm}$ 인 캘리퍼스(530-101, Mitutoyo, Kawasaki, Japan)를 이용하여 측정하였다. 초엽장 의 길이가 $1 \mathrm{~mm}$ 미만인 발아벼는 발아되지 않은 것으로 분류하여 발아율에서 제외하였으며, $1 \mathrm{~mm}$ 이상의 길이로 출아된 벼만 발아된 것으로 간주하여 초엽장의 길이로 측정 하였다.

$$
\text { 발아율 }(\%)=\frac{\text { 싹이 출아된 벼 낟알 수 }}{\text { 전체 벼 낟알 수 }} \times 100
$$

\section{티아민(thiamin) 및 나이아신(niacin) 함량 분석}

분쇄된 발아벼 시료 $3 \mathrm{~g}$ 을 취한 후 $5 \mathrm{mM}$ sodium 1-hexanesulfonate 용액 $25 \mathrm{~mL}$ 을 가하고 혼합하여 초음파 추출기(8893-DTH, Cole-Parmer, Vernon Kills, IL, USA)로 30 분간 추출하였다. 추출액은 소형원심분리기(HM-150IV, Hanil Co., Inchun, Korea)를 사용하여 $374 \times g$ 에서 10 분간 원심분리하고, 상층액을 취해 $0.45 \mu \mathrm{m}$ syringe filter (Advantec, Tokyo, Japan)로 여과하여 HPLC(1200 Series, Agilent Technologies, Santa Clara, CA, USA)로 분석하였다. $\mathrm{HPLC}$ 분석에 사용한 컬럼은 $\mathrm{YMC}-\mathrm{Pack} \mathrm{ODS}-\mathrm{AM}\left(\mathrm{C}_{18}\right.$, $250 \times 4.6 \mathrm{~mm}, 5 \mu \mathrm{m}, \mathrm{YMC}$, Kyoto, Japan)이고, 컬럼 온도는 $40^{\circ} \mathrm{C}$, 검출기는 $\mathrm{PDA}$ (photodiode array detector, Agilent Technologies)를 사용하여 $270 \mathrm{~nm}$ 에서 검출하였고, 이동상 유량은 $0.8 \mathrm{~mL} / \mathrm{min}$ 이었다. 이동상 $\mathrm{A}$ 는 $0.75 \%$ acetic $\operatorname{acid}(\mathrm{v} / \mathrm{v})$ 과 $0.2 \%$ triethylamin(v/v)이 혼합된 $5 \mathrm{mM}$ sodium 
1-hexanesulfonate, 이동상 B는 methanol을 사용하였으며, 분리 조건은 0-8 $\mathrm{min}$ 은 $0 \% \mathrm{~B}, 8-20 \mathrm{~min}$ 은 0-25\% B, 20-30 $\min$ 은 $25-40 \% \mathrm{~B}, 30-31 \mathrm{~min}$ 은 40-0\% B, 그리고 31-39 $\min$ 은 $0 \% \mathrm{~B}$ 조건의 gradient condition을 이용하였다.

\section{엽산 함량 분석}

엽산 함량은 Lactobacillus case가 엽산 농도에 따라 생육 하는 성장도를 측정하는 Chun 등(11)의 방법을 이용하여 분석하였다. L. caser는 실험 당일 depletion media(lactobacilli broth:folic acid casei medium=1:1, v/v)에 접종한 후 $37^{\circ} \mathrm{C}$ 에 서 6시간 배양하여 사용하였다. Folic acid 용액 $(2 \mathrm{ng} / \mathrm{mL})$, ascorbic acid 용액 $(0.1 \mathrm{~g} / \mathrm{mL})$ 및 시료 추출액은 각각 0.45 $\mu \mathrm{m}$ syringe filter로 여과하여 사용하였으며, 시료 추출액은 멸균 증류수를 이용하여 농도에 따라 단계 희석하여 사용하 였다. Depletion media에서 6시간 동안 배양시킨 L. casei broth를 folic acid casei media 배지에 접종 $(5 \mu \mathrm{L} / \mathrm{mL})$ 하고, ascorbic acid 용액 $(10 \mu \mathrm{L} / \mathrm{mL})$ 을 가하여 잘 혼합한 뒤 분석배 지로 준비하였다. 96-well microplate에 단계 희석한 표준용 액과 시료액을 $150 \mu \mathrm{L}$ 씩 넣은 후 준비한 분석배지를 150 $\mu \mathrm{L}$ 씩 가하여 잘 혼합한 후 뚜껑을 덮고 $37^{\circ} \mathrm{C}$ 배양기 (HB-103M, Hanbeak Co., Bucheon, Korea)에서 18-20시간 배양시켰다. Microplate reader(Eon, BioTek Instruments, Inc., St. Winooski, VT, USA)를 이용하여 $595 \mathrm{~nm}$ 에서 표준 용액과 시료 농도에 따른 L casei의 성장 정도를 측정하였 다. 표준용액 농도에 따른 L. casei 생장곡선을 이용하여 시료 중의 엽산 함량을 Bio-Tek의 Gen5 데이터 분석 소프트 웨어를 이용하여 계산하였으며, 시료의 엽산 함량은 $\mu \mathrm{g} / 100$ $\mathrm{g}$ 으로 나타냈다.

\section{$\mathrm{\gamma}$-Aminobutyric acid(GABA) 함량 분석}

$\mathrm{GABA}$ 함량은 Jo 등(12)의 방법을 일부 변형하여 측정하 였다. 시료 $5 \mathrm{~g}$ 을 취한 후 증류수 $25 \mathrm{~mL}$ 을 가하여 homogenizer (T10, IKA, Janke \& Kunkel-Str., Staufen, Germany)를 이용 하여 2 분간 추출한 후 증류수 $5 \mathrm{~mL}$ 을 homogenizer probe를 세척하여 총 추출액으로 혼합하였다. 추출물을 $8,184 \times g$ 로 10 분간 $\left(4^{\circ} \mathrm{C}\right)$ 원심분리(Supra R30, Hanil Co., Inchun, Korea) 한 후 상층액을 $100 \mathrm{~mL}$ 용량플라스크에 취하였다. 침전물 에 증류수 $35 \mathrm{~mL}$ 을 가하여 상기 과정을 반복한 후 추출액으 로 수거한 후 증류수를 이용하여 $100 \mathrm{~mL}$ 이 되도록 정용하 였다. 추출액을 잘 혼합한 후 $1 \mathrm{~mL}$ 을 취하여 $374 \times g$ 에서 10 분간 원심분리한 다음 상등액을 $0.45 \mu \mathrm{m}$ syringe filter로 여과하였다. 여과액은 AccQ-Tag Amino Acid Analysis (Waters Co., Milford, MA, USA)에 따라 유도체화한 다음 HPLC(Agilent)로 분석하였다. HPLC 분석에 사용한 컬럼은 ZORBOX Eclipse XDB $\mathrm{C}_{18}(150 \times 4.6 \mathrm{~mm}, 5 \mu \mathrm{m}$, Agilent $)$ 였으 며, 검출은 fluorescence detector(Agilent)를 사용하여 여기 파장 $340 \mathrm{~nm}$, 측정파장 $435 \mathrm{~nm}$ 에서 검출하였다. 추출액의
$\mathrm{GABA}$ 는 이동상 $\mathrm{A}: \mathrm{pH} 7.8$ 로 조정한 $40 \mathrm{mM} \mathrm{NaH} \mathrm{PO}_{4}$ 와 이동상 B: acetonitril:methanol:water=4.5:4.5:1(v/v/v)를 다 음과 같은 gradient condition을 이용하여 분리하였다: 0-3.8 $\min , 0 \% \mathrm{~B} ; 3.8-28 \mathrm{~min}, 0-50 \% \mathrm{~B} ; 28-36 \mathrm{~min}, 50-100 \% \mathrm{~B}$; $36-44 \mathrm{~min}, 100-0 \% \mathrm{~B} ; 44-50 \mathrm{~min}, 0 \% \mathrm{~B}$. 이동상 유량은 $1 \mathrm{~mL} / \mathrm{min}$ 이었다.

\section{유리당 함량 분석}

유리당 함량은 Wilson 등(13)의 방법에 준하여 분석하였 다. 분쇄된 시료 $2 \mathrm{~g}$ 에 증류수를 가하여 교반시킨 후 100 $\mathrm{mL}$ 로 정용하여 원심분리 $(3,000 \times \mathrm{g}, 30 \mathrm{~min})$ 하고 상층액을 취하여 여과(Whatman No.2)하였다. 여과액은 Sep-pak $\mathrm{C}_{18}$, 으로 정제시킨 다음, $0.45 \mu \mathrm{m}$ syringe filter로 여과 후 HPLC(Agilent)를 이용하여 분석하였다. HPLC 분석에 사용 한 컬럼은 carbohydrate column $(250 \times 4.6 \mathrm{~mm}$, Alltech Co., Lexington, $\mathrm{KY}, \mathrm{USA}$ )이었고, 검출기는 $\mathrm{ELSD}$ (Evaporative Light Scattering Detector, Agilent)를 사용하였으며, 이동상 은 $75 \%$ acetonitrile을 이용한 isocratic condition이었으며 이동상 유량은 $1 \mathrm{~mL} / \mathrm{min}$ 이었다.

\section{당화 특성 조사}

발아벼의 당화특성은 당화액을 제조한 후 당도를 측정하 여 비교하였다. 당화액 제조는 필스너형 맥주 제조 시 맥아 가 사용되는 당화공정 조건에서 맥아 대신 발아벼를 사용하 여 제조하였다. 발아벼 $6 \mathrm{~g}$ 과 증류수 $25 \mathrm{~mL}$ 을 $50 \mathrm{~mL}$ cornical tube에 넣어 혼합한 후 뚜껑을 닫고 진탕항온수조 (HB-205SW, Hanbeak Co., Bucheon, Korea)에서, $45^{\circ} \mathrm{C}$ 에서 20 분, $60^{\circ} \mathrm{C}$ 에서 25 분, $65^{\circ} \mathrm{C}$ 에서 80 분, $72^{\circ} \mathrm{C}$ 에서 15 분, $78^{\circ} \mathrm{C}$ 에 서 5 분간 순차적으로 정치하면서 당화액을 제조하였다. 당 화액의 당도는 당도계(PR-101, Atago, Tokyo, Japan)를 이용 하여 측정하였으며 당화 실험은 3반복하여 각각의 당도를 측정하고 평균값을 계산하였다.

\section{통계 분석}

실험결과는 SPSS(Statistics Package for the Social Science, Ver. 22.0 for Window, SPSS Inc., Chicago, IL, USA) 프로그램을 이용하여 분석하였으며, 평균과 표준편차를 구 하고 Duncan 다중범위검정(Duncan's multiple range test)과 Student t-test를 이용하여 $\mathrm{p}<0.05$ 수준에서 유의성을 검정하 였다.

\section{결과 및 고찰}

\section{침지 시간에 따른 발아벼의 발아율 및 초엽장 분포}

벼를 $35^{\circ} \mathrm{C}$ 에서 $8,16,24$ 시간 동안 각각 침지시킨 다음, $30^{\circ} \mathrm{C}$ 에 상대습도 $90 \%$ 로 조절된 plant growth chamber에서 
24시간 동안 발아시킨 후 벼의 발아율과 초엽장(발아된 싹)의 길이를 측정하여 Table 1 과 같이 초엽장의 길이를 6단계(<1, 1-2, 2-3, 3-4, 4-5, $5 \mathrm{~mm}$ 이상)로 구분하여 나타내 었다. 침지 시간 8-24시간에 따라 초엽장 길이 분포도가 유의적으로 차이를 보이는 것으로 나타났다 $(\mathrm{p}<0.05)$. 발아 전 8시간 동안 침지된 발아벼는 모두 초엽장이 $3 \mathrm{~mm}$ 이하를 나타냈는데 이 중 1-2 mm로 짧은 발아벼가 $92.4 \%$ 로 대부분 을 차지하였다. 이와 달리, 발아 전 16 시간과 24 시간 동안 침지시킨 후 발아시킨 벼는 초엽장에 따라 구분된 6단계에 서 비교적 고른 분포를 보이며 발아된 것을 확인할 수 있었 다. 한편, 초엽장이 1-2 mm로 짧은 발아벼는 16 시간 침지 시 $71.2 \%, 24$ 시간 침지 시 $52.0 \%$ 의 분포를 나타내어 8 시간 침지된 벼에 비하여 크게 감소되는 것을 확인할 수 있었다. 전체적으로 발아 전 침지 시간이 길어질수록 $3 \mathrm{~mm}$ 이상의 초엽장을 보이는 발아벼의 비율이 높아지고, 초엽장 길이 도 고르게 분포되는 경향을 보였다. 한편, 미발아율(발아되 지 않는 벼의 비율)과 총발아율은 8-24시간 침지 시간에 따라 각각 5.6-6.0\%와 94.0-95.2\%를 나타내었는데 침지 시 간에 따른 유의적인 차이는 관찰되지 않았다.

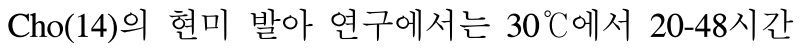
동안 침지한 후 발아시킨 결과, 침지 24 시간까지는 발아율 이 증가하였으나 36 시간 이상 침지하는 경우 현미 전분이 발효되는 현상이 관찰되었다고 보고하여 장시간의 침지는 미생물에 의한 변화에 대한 주의가 필요함을 제시하였다. 한편, Palmiano와 Juliano(15)의 연구에서도 쌀 발아 시 최적 침지 시간은 18-24시간이며, 24시간 이상의 침지는 부패취 를 유발하기 때문에 식품 원료로 사용하기에 부적합하다고 보고하였다. 이러한 연구는 충분한 침지는 발아에 효율적 이나 적정 시간 이상의 침지는 오히려 부패나 발효를 유발 할 수 있음을 보여주는 것으로 쌀 발아의 발아율이 고르게

Table 1. Table 1. Sprout length and germination ratio of unhulled-rice germinated for $24 \mathrm{~h}$ at $30^{\circ} \mathrm{C}$ after steeping for different time

\begin{tabular}{cccc}
\hline \multirow{2}{*}{ Sprout length } & \multicolumn{3}{c}{ Germination ratio $(\%)^{\mathrm{l})}$} \\
\cline { 2 - 4 } & $8 \mathrm{~h}$ steeping & $16 \mathrm{~h}$ steeping & $24 \mathrm{~h}$ steeping \\
\hline None $(<1 \mathrm{~mm})$ & $\left.5.6 \pm 5.2^{\mathrm{Ab} 2}\right)$ & $4.8 \pm 2.7^{\mathrm{Abc}}$ & $6.0 \pm 2.0^{\mathrm{Ac}}$ \\
$1-2 \mathrm{~mm}$ & $92.4 \pm 5.2^{\mathrm{Aa}}$ & $71.2 \pm 5.2^{\mathrm{Ba}}$ & $52.0 \pm 3.2^{\mathrm{Ca}}$ \\
$2-3 \mathrm{~mm}$ & $2.0 \pm 2.0^{\mathrm{Cbc}}$ & $7.6 \pm 2.6^{\mathrm{Bb}}$ & $11.6 \pm 3.3^{\mathrm{Ab}}$ \\
$3-4 \mathrm{~mm}$ & $0^{\mathrm{Cc}}$ & $7.2 \pm 1.1^{\mathrm{Bbc}}$ & $9.2 \pm 1.8^{\mathrm{Abc}}$ \\
$4-5 \mathrm{~mm}$ & $0^{\mathrm{Cc}}$ & $6.0 \pm 2.4^{\mathrm{Bbc}}$ & $11.2 \pm 3.0^{\mathrm{Ab}}$ \\
$>5 \mathrm{~mm}$ & $0^{\mathrm{Bc}}$ & $3.2 \pm 2.3^{\mathrm{Bc}}$ & $7.2 \pm 3.3^{\mathrm{Ac}}$ \\
\hline Total germination ratio $(\%)$ & $94.4 \pm 5.2^{\mathrm{A}}$ & $95.2 \pm 2.7^{\mathrm{A}}$ & $94.0 \pm 2.0^{\mathrm{A}}$
\end{tabular}

1) Germination ratio $(\%)=100 \times \frac{\text { Number of germinated rice }}{\text { Total number of dehulled rice }}$

${ }^{2)}$ Values with different small letters in the same column are significantly different by Duncan's multiple range test $(p<0.05)$. $(a>b>c)$. Values with different capital letters in the same row are significantly different by Duncan's multiple range test $(p<0.05) .(A>B>C)$.
분포되면서도 이러한 부정적인 변화를 일으키지 않는 침지 시간을 품종에 따라 확인하는 것이 필요하다 하겠다. 본 연구에서는 이러한 선행연구를 근거로 침지 시간을 최대 24시간까지로 설정하여 새일미 발아특성을 조사하였으며, 그 결과 $35^{\circ}$ C에서 24 시간 동안 침지 시 부패취나 발효 현상 은 관찰되지 않았으며 침지 24시간에서 발아율이 가장 고 르게 분포되어 최대 24시간까지 침지가 가능한 것으로 판 단된다.

침지 시간에 따른 발아벼의 티아민(thiamin), 나이아신 (niacin) 및 엽산(folate) 함량 변화

$35^{\circ} \mathrm{C}$ 에서 $8,16,24$ 시간 동안 침지한 후 $30^{\circ} \mathrm{C}$ 에서 24 시간 동안 발아시킨 벼의 수용성 비타민 함량을 측정한 결과는 Table 2와 같다. 티아민 함량은 발아 전 $483.86 \mathrm{\mu g} / 100 \mathrm{~g}$ 이었 는데, 발아 후 침지 시간에 따라 약 4-13\% 증가하는 것으로 나타났다. 나이아신 함량은 발아 전 $418.84 \mathrm{\mu g} / 100 \mathrm{~g}$ 에서 발아 후 침지시간에 따라 약 3-4배 증가한 1,262.74-1,529.71 $\mu \mathrm{g} / 100 \mathrm{~g}$ 의 범위를 보였으며, 8시간 침지 후 발아시킨 벼에 서 가장 높은 함량을 보였고 침지 시간이 길어질수록 유의 적으로 감소하였다 $(\mathrm{p}<0.05)$. 또한, 엽산의 경우도 침지시간 이 길어질수록 증가하였는데, 24 시간 동안 침지된 발아벼 의 경우 발아전에 비하여 엽산 함량이 약 2.2 배 증가된 50.98 $\mu \mathrm{g} / 100 \mathrm{~g}$ 을 나타내었다. Lee 등(16)의 연구에서도 큰 눈과 일품 발아미를 발아 시 나이아신 함량이 발아 전에 비하여 약 2.5-8.7배까지 증가되었다고 보고하여 본 연구에서 관찰 된 발아에 의한 수용성 비타민 함량의 증가와 유사한 결과 와 일치하였다.

\section{침지 시간에 따른 발아벼의 $\mathrm{\gamma}$-aminobutyric acid (GABA) 함량 변화}

GABA는 glutamate decarboxylase(GAD)의 탈탄산 작용 에 의하여 glutamic acid로부터 생성되며, 섭취 시 동물 체내 에서 중추신경계의 신경전달 물질로서 뇌 세포의 대사 기능 을 촉진시키고(17), 혈압 강하와 알코올 대사를 증진시키는 기능을 나타내는 것으로 알려져 있다(18). 한편, 식물체에 서의 GABA 생성은 산소나 빛이 부족하거나, 저온이나 고 온과 같은 극한 외부적 요인에 의해 촉진될 수 있는 것으로 알려져 있으며(19), 곡물은 발아 시 수침 과정에서 $\mathrm{GAD}$ 효소 활성, 수분 흡수율, $\mathrm{pH}$, 미생물 증식 등의 이화학적 변화의 영향을 받는 것으로 알려져 있다(20).

본 연구에서 사용된 새일미의 발아 전 $\mathrm{GABA}$ 함량은 $7.73 \mathrm{mg} / 100 \mathrm{~g}$ 이었으며, 침지 시간에 따라 발아벼의 GABA 함량이 $13.86-21.29 \mathrm{mg} / 100 \mathrm{~g}$ 으로 약 2-3배 증가되었다 (Table 3). 발아벼의 GABA 함량은 8시간 침지된 시료에서 $21.29 \mathrm{mg} / 100 \mathrm{~g}$ 으로 가장 높게 나타났으며 이보다 침지 시간이 길어진 경우 $\mathrm{GABA}$ 함량이 낮아진 것을 확인할 수 있었다. Lee(16)는 침지 온도를 달리하고 침지 시간별 
Table 2. Thiamin, niacin, and folate contents of unhulled rice germinated for $24 \mathrm{~h}$ at $35^{\circ} \mathrm{C}$ after steeping for different time (dry basis)

\begin{tabular}{cccc}
\hline Samples & $\begin{array}{c}\text { Thiamin content } \\
(\mu \mathrm{g} / 100 \mathrm{~g})\end{array}$ & $\begin{array}{c}\text { Niacin content } \\
(\mu \mathrm{g} / 100 \mathrm{~g})\end{array}$ & $\begin{array}{c}\text { Folate content } \\
(\mu \mathrm{g} / 100 \mathrm{~g})\end{array}$ \\
\hline Non-germinated rice & $483.86 \pm 2.69^{\mathrm{cl}}$ & $418.84 \pm 62.36^{\mathrm{c}}$ & $23.61 \pm 0.19^{\mathrm{d}}$ \\
Germinated rice after steeping for $8 \mathrm{~h}$ & $549.95 \pm 15.86^{\mathrm{a}}$ & $1,529.71 \pm 36.98^{\mathrm{a}}$ & $30.30 \pm 0.33^{\mathrm{c}}$ \\
Germinated rice after steeping for $16 \mathrm{~h}$ & $506.02 \pm 5.17^{\mathrm{b}}$ & $1,476.05 \pm 41.61^{\mathrm{a}}$ & $35.82 \pm 1.38^{\mathrm{b}}$ \\
Germinated rice after steeping for $24 \mathrm{~h}$ & $534.59 \pm 4.32^{\mathrm{a}}$ & $1,262.74 \pm 88.80^{\mathrm{b}}$ & $50.98 \pm 1.68^{\mathrm{a}}$ \\
\hline
\end{tabular}

${ }^{1}$ Values with different small letters in the same column are significantly different by Duncan's multiple range test $(\mathrm{p}<0.05)$. $(\mathrm{a}>\mathrm{b}>\mathrm{c}>\mathrm{d})$.

Table 3. GABA and free sugars contents (dry basis) and saccharification power of unhulled rice germinated at $35^{\circ} \mathrm{C}$ for $24 \mathrm{~h}$ after steeping for different time

\begin{tabular}{|c|c|c|c|c|c|c|c|}
\hline \multirow{2}{*}{ Samples ${ }^{1)}$} & \multirow{2}{*}{$\begin{array}{l}\text { GABA content } \\
(\mathrm{mg} / 100 \mathrm{~g})\end{array}$} & \multicolumn{5}{|c|}{ Free sugar contents $(\%)$} & \multirow{2}{*}{$\begin{array}{c}\text { Soluble sugar content } \\
\text { of saccharified soln. }{ }^{2)}\left({ }^{\circ} \text { Brix }\right)\end{array}$} \\
\hline & & Fructose & Glucose & Maltose & Sucrose & Total & \\
\hline Non-germinated rice & $7.73 \pm 0.21^{\mathrm{cl})}$ & - & $1.68 \pm 0.08^{\mathrm{c}}$ & - & - & $1.68 \pm 0.08^{c}$ & $4.6 \pm 0.2^{(3)}$ \\
\hline Germinated rice after steeping for $8 \mathrm{~h}$ & $21.29 \pm 1.54^{\mathrm{a}}$ & $0.21 \pm 0.03^{\mathrm{a}}$ & $14.25 \pm 0.54^{\mathrm{b}}$ & - & - & $14.46 \pm 0.57^{\mathrm{b}}$ & $7.1 \pm 0.7^{\mathrm{b}}$ \\
\hline Germinated rice after steeping for $16 \mathrm{~h}$ & $14.11 \pm 0.84^{b}$ & - & $16.87 \pm 1.45^{\mathrm{a}}$ & - & - & $16.87 \pm 1.45^{\mathrm{a}}$ & $9.8 \pm 0.2^{\mathrm{a}}$ \\
\hline Germinated rice after steeping for $24 \mathrm{~h}$ & $13.86 \pm 0.91^{\mathrm{b}}$ & - & $17.89 \pm 1.00^{\mathrm{a}}$ & - & - & $17.89 \pm 1.00^{\mathrm{a}}$ & $9.7 \pm 0.2^{\mathrm{a}}$ \\
\hline
\end{tabular}

${ }^{1)}$ Values with different small letters in the same column are significantly different by Duncan's multiple range test $(\mathrm{p}<0.05)$. $(\mathrm{a}>\mathrm{b}>\mathrm{c})$.

${ }^{2)}$ Saccharified solution was obtained by incubation of germinated rice in water at $45^{\circ} \mathrm{C}$ for $20 \mathrm{~min}$, at $60^{\circ} \mathrm{C}$ for $25 \mathrm{~min}$, at $65^{\circ} \mathrm{C}$ for $80 \mathrm{~min}$, at $72^{\circ} \mathrm{C}$ for $15 \mathrm{~min}$, and at $78^{\circ} \mathrm{C}$ for $5 \mathrm{~min}$

발아현미의 $\mathrm{GABA}$ 함량 변화를 측정한 결과, $25^{\circ} \mathrm{C}$ 에서 는 24 시간, $35^{\circ} \mathrm{C}$ 와 $30^{\circ} \mathrm{C}$ 에서는 18 시간 침지시킨 발아현미 에서 최대 GABA 함량 수준을 보였으나, 그 이상의 침지 시간에서는 $\mathrm{GABA}$ 함량이 오히려 감소되었다고 보고하였 다. Cha 등(21)의 발아보리 연구에서는 수침 온도가 높아질 수록 $\mathrm{GABA}$ 함량이 최대치가 되는 침지 시간이 짧아져 $10^{\circ} \mathrm{C}, 15^{\circ} \mathrm{C}, 40^{\circ} \mathrm{C}$ 에서는 8 시간의 침지시간이 필요하였으나 $50^{\circ} \mathrm{C}$ 에서는 2 시간 침지 시 $\mathrm{GABA}$ 함량이 가장 높았다고 보고하였다. 또한, Jeon 등(22)의 연구도 수침 18-25시간에 서 GABA 함량이 가장 높았고 이후 감소하는 경향을 보였 으며, $35^{\circ} \mathrm{C}$ 에서 온도가 증가할수록 $\mathrm{GABA}$ 함량이 높아지는 것으로 보고하였다. 이러한 선행 연구들은 적정 침지 조건 에서는 GABA 함량이 증가될 수 있으나 쌀의 품종에 따라 그 이상의 침지 조건에서는 오히려 GABA 생성이 저해됨을 보여준다 하겠다. 본 연구에서는 침지 온도 $35^{\circ} \mathrm{C}$ 에서 8-24 시간 동안 침지한 결과, 8 시간 침지 후 발아시킨 벼에서 가장 높은 $\mathrm{GABA}$ 함량이 관찰되어 선행 연구에서 보고된 현미와 보리 발아 시 최대 GABA함량을 얻기 위한 침지 시간보다 짧은 침지 시간이 요구되는 것으로 보여진다.

\section{침지 시간에 따른 발아벼의 유리당 함량 변화 및 당화 특성}

$35^{\circ} \mathrm{C}$ 에서 8,16 , 그리고 24 시간 동안 침지한 후 $30^{\circ} \mathrm{C}$ 에서 24시간 발아시킨 벼의 유리당 함량은 Table 3과 같다. 새일 미의 glucose 함량은 발아 전의 $1.68 \%$ 에 비하여 발아 후 침지 시간에 따라 약 7-9배 증가되었다. 침지 8시간보다 16 시간과 24시간 침지 후 발아된 시료의 glucose 함량이
유의적으로 높았으며( $\mathrm{p}<0.05), 16$ 시간과 24 시간 침지 시료 간에는 유의적인 차이는 관찰되지 않았다. 유리당 중 fructose는 발아 전에는 관찰되지 않았으나 8시간 침지 후 발아된 시료에서 미량 검출되었으며, 16 시간과 24 시간 침 지 후 발아된 시료에서는 관찰되지 않았다. 식물체 발아 시 유리당 함량이 변화하는 것은 발아 시 생명활동을 위해 효소가 활성화되고, 당류가 유리당으로 분해되면서 이를 이용하여 싹이 자라기 때문에 나타나는 것으로 알려져 있 다. 이와 같이 발아에 의해 유리당의 종류와 함량이 변화되 는 특성은 다양한 식물체에서도 관찰되는데 $\mathrm{Kim}$ 등(23)의 연구에서 유채는 fructose가 발아 초기에 감소하여 발아 48 시간에서 최저치를 보인 후 72 시간부터 서서히 증가하였 고, glucose는 96시간에 최저치를 보인 후 다시 증가되었으 며, Aman(24)의 연구에서 mung bean과 chick pea는 발아 중 fructose는 계속 증가하지만 glucose와 sucrose는 증가하 다가 발아 72시간 이후 완전히 소실되는 것으로 보고되었 다. 메밀의 경우도 발아 시 glucose는 발아 3 일째까지 감소 하다가 5일 이후 급격히 증가하여 초기 수준보다 5배 높아 졌으며(25), 벼에서도 fructose 함량이 발아에 의해 증가되 는 것으로 나타났다(26).

한편, $35^{\circ} \mathrm{C}$ 에서 $8,16,24$ 시간 동안 침지 후 $30^{\circ} \mathrm{C}$ 에서 24 시간 동안 발아시킨 벼의 당화특성을 조사한 결과는 Table 3과 같다. 8시간 침지 후 발아된 벼를 이용하여 제조한 당화액의 당도는 $7.1{ }^{\circ} \mathrm{Brix}$ 였으며, 16 시간과 24 시간 침지 후 발아된 벼의 경우는 약 $10{ }^{\circ} \mathrm{Brix}$ 를 나타내어 효소의 활성 이 보다 높아진 것으로 보여진다. 이는 8시간 침지 후 발아 
된 벼의 초엽장 길이가 대부분 약 $3 \mathrm{~mm}$ 이하인 반면, 16 시간 과 24시간 침지 후 발아된 벼의 초엽장은 $5 \mathrm{~mm}$ 길이까지 고르게 분포된 것을 볼 때(Table 1), 침지 시간이 18 시간 이상의 경우 발아가 전체적으로 고르게 진행되며 싹의 길이 가 길어지는데 이는 싹을 틔우기 위한 효소의 활성도 보다 높아지기 때문이라 하겠다.

침지 시간에 따른 새일미 발아벼의 특성을 조사한 결과, 8 시간 침지보다는 16 시간과 24 시간 침지에서 엽산 및 유리 당 함량의 증가가 높게 나타났고 당화력도 개선되었으나 침지 시간 16 시간과 24 시간 간에는 이러한 특성 차이가 유의적이지 않았다. 한편, 24 시간 침지된 발아벼의 초엽장 이 보다 길어지고 고르게 분포되는 것이 관찰되었으며 영양 및 기능성 성분과 효소 활성 면에서도 최고값은 아니지만 높은 수준의 값을 나타내었기 때문에 이후 발아 시간에 따른 발아벼의 특성 조사를 위하여 24시간을 적정 침지 시간으로 선정하여 이후 실험을 진행하였다.

\section{발아 시간에 따른 발아벼의 발아율 및 초엽장 분포}

벼를 $35^{\circ} \mathrm{C}$ 에서 24 시간 동안 침지시킨 후 $30^{\circ} \mathrm{C}$ growth chamber(상대습도 $90 \%$ )에서 $20,24,28,32$ 시간 동안 발아 시킨 벼의 발아율 및 초엽장 분포를 조사한 결과는 Table 4 와 같다. 발아된 싹의 길이에 따라 발아율을 분류한 결과, 20 시간과 24시간 동안 발아된 벼의 초엽장은 모두 $6 \mathrm{~mm}$ 이하인 반면, 28 시간과 32 시간의 경우 초엽장이 전체적으 로 보다 길어진 것을 확인할 수 있었다. 발아 시간이 가장 짧은 20시간에서는 1-2 mm에 속하는 초엽장을 보이는 발아 벼가 $78 \%$ 를 차지하였으며, 24-32시간 발아된 벼의 경우,
초엽장이 1-2 mm에 속하는 발아벼가 52.0-52.4\% 범위로 짧은 초엽장을 가진 발아벼 비율이 낮아지는 것으로 나타났 다. 발아 시간이 길어질수록 초엽장의 길이가 길어지는 것 으로 나타나 32시간 발아된 벼에서 $10 \mathrm{~mm}$ 이상의 초엽장을 보인 발아벼 비율이 $10.4 \%$ 로 가장 높았다. 한편, 초엽장 길이 분포와 상관없이 총 발아율은 $93.2-95.6 \%$ 의 범위를 보였으며 발아 시간에 따른 유의적인 차이는 나타나지 않았 다. Kim과 Lee(27)는 일품벼 품종에서 $90 \%$ 이상의 발아율 을 얻기 위해서는 $15^{\circ} \mathrm{C}$ 에서 2 일 동안 침지시킨 후 $30^{\circ} \mathrm{C}$ 에서 $3-4$ 일, $20^{\circ} \mathrm{C}$ 에서는 7-8일의 발아 기간이 소요되었다고 보고 하여 본 연구 결과와는 다소 차이를 보였는데 이는 주로 벼의 품종에 따른 특성 때문인 것으로 사료된다.

\section{발아 시간에 따른 발아벼의 티아민, 나이아신 및 엽산 함 량 변화}

벼를 $35^{\circ} \mathrm{C}$ 에서 24 시간 동안 침지 후 $30^{\circ} \mathrm{C}$ 에서 20-32시간 동안 발아시키면서 티아민, 나이아신, 엽산 함량의 변화를 측정한 결과는 Table 5 와 같다. 전체적으로 발아에 의하여 수용성 비타민 함량이 증가하는 경향을 보였는데, 티아민 과 나이아신의 경우, 발아 전 각각 $483.86 \mu \mathrm{g} / 100 \mathrm{~g}$ 과 418.84 $\mu \mathrm{g} / 100 \mathrm{~g}$ 수준에서 발아 24시간 후 각각 $534.59 \mathrm{\mu g} / 100 \mathrm{~g}$ 과 $1,275.12 \mu \mathrm{g} / 100 \mathrm{~g}$ 으로 증가하였으나 24시간 이상의 발아에 서는 유의적인 변화가 없거나 다소 감소하는 경향을 나타냈 다. 한편, 엽산의 경우 발아 32시간까지 지속적으로 증가하 여 가장 높은 값(58.93 $\mathrm{\mu g} / 100 \mathrm{~g})$ 을 나타내었다. 이렇게 발아 에 의해 증가된 티아민, 나이아신, 엽산 함량은 발아 전에 비하여 각각 약 $1.1,3.0,2.5$ 배 증가된 수준이었다.

Table 4. Sprout length and germination rate of unhulled rice germinated at $30^{\circ} \mathrm{C}$ for different time after steeping for $24 \mathrm{~h}$

\begin{tabular}{|c|c|c|c|c|}
\hline \multirow{2}{*}{ Sprout length } & \multicolumn{4}{|c|}{ Germination ratio $(\%)^{1)}$} \\
\hline & $20 \mathrm{~h}$ germination & $24 \mathrm{~h}$ germination & $28 \mathrm{~h}$ germination & $32 \mathrm{~h}$ germination \\
\hline None $(<1 \mathrm{~mm})$ & $6.8 \pm 3.9^{\mathrm{Ab} 2)}$ & $6.0 \pm 2.0^{\mathrm{Ad}}$ & $5.2 \pm 2.3^{\text {Acde }}$ & $4.4 \pm 1.7^{\mathrm{Ac}}$ \\
\hline $1-2 \mathrm{~mm}$ & $78.0 \pm 4.0^{\mathrm{Aa}}$ & $52.0 \pm 3.2^{\mathrm{Ba}}$ & $52.4 \pm 12.3^{\mathrm{Ba}}$ & $52.0 \pm 18.0^{\mathrm{Ba}}$ \\
\hline $2-3 \mathrm{~mm}$ & $9.2 \pm 2.3^{\mathrm{Bb}}$ & $11.6 \pm 3.3^{\mathrm{Ab}}$ & $11.6 \pm 3.6^{\mathrm{Abc}}$ & $6.0 \pm 2.4^{\mathrm{Bbc}}$ \\
\hline 3-4 mm & $0.0 \pm 0.0^{\mathrm{Ce}}$ & $9.2 \pm 1.8^{\mathrm{Abc}}$ & $2.8 \pm 2.3^{\text {Bde }}$ & $9.6 \pm 1.7^{\mathrm{Abc}}$ \\
\hline $4-5 \mathrm{~mm}$ & $4.0 \pm 2.4^{\mathrm{Cc}}$ & $11.2 \pm 3.0^{\mathrm{Bb}}$ & $13.6 \pm 6.2^{\mathrm{Ab}}$ & $2.4 \pm 2.6^{\mathrm{Cc}}$ \\
\hline $5-6 \mathrm{~mm}$ & $2.0 \pm 2.4^{\mathrm{Bcd}}$ & $7.2 \pm 3.3^{\text {Acd }}$ & $4.0 \pm 5.5^{\mathrm{ABcde}}$ & $8.8 \pm 2.3^{\mathrm{Abc}}$ \\
\hline $6-7 \mathrm{~mm}$ & $0^{\mathrm{Cd}}$ & $0^{\mathrm{Ce}}$ & $2.8 \pm 2.3^{\mathrm{Bde}}$ & $8.0 \pm 2.4^{\mathrm{Abc}}$ \\
\hline $7-8 \mathrm{~mm}$ & $0^{\mathrm{Bd}}$ & $0^{\mathrm{Be}}$ & $10.4 \pm 6.8^{\mathrm{Abcd}}$ & $13.6 \pm 1.7^{\mathrm{Ab}}$ \\
\hline $8-9 \mathrm{~mm}$ & $0^{\mathrm{Bd}}$ & $0^{\mathrm{Be}}$ & $6.4 \pm 4.3^{\text {Abcde }}$ & $5.6 \pm 1.7^{\mathrm{Abc}}$ \\
\hline $9-10 \mathrm{~mm}$ & $0^{\mathrm{Cd}}$ & $0^{\mathrm{Ce}}$ & $2.0 \pm 2.4^{\mathrm{Be}}$ & $10.8 \pm 1.1^{\mathrm{Abc}}$ \\
\hline$>10 \mathrm{~mm}$ & $0^{\mathrm{Cd}}$ & $0^{\mathrm{Ce}}$ & $3.2 \pm 2.3^{\text {Bde }}$ & $10.4 \pm 1.7^{\mathrm{Abc}}$ \\
\hline Total germination ratio $(\%)$ & $93.2 \pm 3.9^{A}$ & $94.0 \pm 2.0^{\mathrm{A}}$ & $94.8 \pm 2.3^{\mathrm{A}}$ & $95.6 \pm 1.7^{\mathrm{A}}$ \\
\hline
\end{tabular}

1) Germination ratio $(\%)=100 \times \frac{\text { Number of germinated rice }}{\text { Total number of dehulled rice }}$

${ }^{2)}$ Values with different small letters in the same column are significantly different by Duncan's multiple range test $(\mathrm{p}<0.05)$. ( $\left.\mathrm{a}>\mathrm{b}>\mathrm{c}>\mathrm{d}>\mathrm{e}\right)$. Values with different capital letters in the same row are significantly different by Duncan's multiple range test $(\mathrm{p}<0.05)$. $(A>B>C)$. 
$\mathrm{Mo}$ 등(28)은 현미를 $27^{\circ} \mathrm{C}$ 에서 발아 시 40 시간 동안 비타 민 B2(riboflavin)는 증가하였으나 티아민과 나이아신은 모 두 급격히 감소하였다고 보고하였고, Khalil과 Mansour(29) 은 faba bean 발아 시 수용성 비타민 함량이 감소되었다고 보고하여 본 연구에서 발아에 의해 수용성 비타민이 증가한 결과와는 다른 양상을 나타냈다. 발아 시 이러한 수용성 비타민 함량의 변화는 쌀의 품질, 침지 및 발아 조건에 영향 을 받게 되므로(30) 선행 연구 결과와 절대적인 수치를 비교 하기 어려운 것으로 판단된다.

Table 5. Niacin, thiamin, and folate contents of unhulled rice germinated at $30^{\circ} \mathrm{C}$ for different time after steeping for $24 \mathrm{~h}$ (dry basis)

\begin{tabular}{cccc}
\hline Samples & $\begin{array}{c}\text { Thiamin content } \\
(\mu \mathrm{g} / 100 \mathrm{~g})\end{array}$ & $\begin{array}{c}\text { Niacin content } \\
(\mu \mathrm{g} / 100 \mathrm{~g})\end{array}$ & $\begin{array}{c}\text { Folic acid content } \\
(\mu \mathrm{g} / 100 \mathrm{~g})\end{array}$ \\
\hline Non-germinated rice & $483.86 \pm 2.69^{\mathrm{d} 1)}$ & $418.84 \pm 62.36^{\mathrm{c}}$ & $23.61 \pm 0.19^{\mathrm{d}}$ \\
Germinated rice for 20 h & $503.58 \pm 8.43^{\mathrm{cd}}$ & $1157.26 \pm 43.25^{\mathrm{b}}$ & $34.83 \pm 1.25^{\mathrm{c}}$ \\
Germinated rice for 24 h & $534.59 \pm 4.32^{\mathrm{a}}$ & $1275.12 \pm 53.75^{\mathrm{a}}$ & $50.98 \pm 1.68^{\mathrm{b}}$ \\
Germinated rice for 28 h & $510.91 \pm 14.35^{\mathrm{bc}}$ & $1288.43 \pm 34.26^{\mathrm{a}}$ & $50.58 \pm 1.60^{\mathrm{b}}$ \\
Germinated rice for 32 h & $526.56 \pm 8.27^{\mathrm{ab}}$ & $1217.65 \pm 0.26^{\mathrm{ab}}$ & $58.93 \pm 3.15^{\mathrm{a}}$ \\
\hline${ }^{1)}$ Values with different small letters in the & same column are significantly different \\
by Duncan's multiple range test $(\mathrm{p}<0.05) .(\mathrm{a}>\mathrm{b}>\mathrm{c}>\mathrm{d})$.
\end{tabular}

발아 시간에 따른 발아벼의 r-aminobutyric acid(GABA) 함량 변화

벼를 $35^{\circ} \mathrm{C}$ 에서 24 시간 동안 침지 후 $30^{\circ} \mathrm{C}$ 에서 20-32시간 동안 발아시키면서 조사한 GABA 함량 변화는 Table 6과 같다. 발아 전 벼의 GABA 함량은 $7.73 \mathrm{mg} / 100 \mathrm{~g}$ 이었는데, 발아 20시간에서 최대 함량인 $16.28 \mathrm{mg} / 100 \mathrm{~g}$ 에 도달하였으 며 이후 발아 시간이 길어질수록 유의적으로 감소되어 $(\mathrm{p}<0.05)$, 발아 32 시간에서는 $6.17 \mathrm{mg} / 100 \mathrm{~g}$ 으로 발아 전의 수준과 유의적인 차이가 없는 수준으로 감소하였다. An 등(31)은 국내산 현미, 녹미, 홍미, 흑미 등 유색미를 발아 시 발아 전에 비하여 GABA 함량이 2.5-11.1배로 증가되었 다고 보고하였고, Kaur 등(32)은 인도 현미 10 종을 $28-30^{\circ} \mathrm{C}$
에서 48 시간 발아 시 $\mathrm{GABA}$ 함량이 약 5 배 증가하여 14.5-20.5 mg/100 g을 나타냈다고 보고하였다. Ko 등(33)은 96시간 동안 발아 시 최대 GABA 함량을 보인 발아시간은 황금조와 청차조의 경우 24 시간, 붉은기장은 84 시간, 노란 찰기장은 36시간, 황금찰수수는 48시간, 흰 찰수수는 72 시 간이었으며 이후의 발아 시간에서는 오히려 GABA 함량이 감소되었다고 보고하였다. 이와 같은 연구 결과들은 곡류 의 종류, 산지 및 품종에 따라 발아 시 $\mathrm{GABA}$ 함량의 증가 특성이 다르게 나타나며 일반적으로 일정 조건까지 GABA 가 증가하다가 다시 감소되는 것을 보여준다 하겠다. 한편, Lee(16)는 현미의 GABA 함량이 a-amylase 함량이 높은 품종일수록 $\mathrm{GABA}$ 함량이 높다고 보고하여 품종에 따라 초기 GABA 함량 수준이 차이를 나타낼 수 있음을 나타내 었다. 가공 중 $\mathrm{GABA}$ 의 합성은 전통 된장의 숙성 과정이나 녹차의 혐기적 가공 과정 중에서도 관찰되는데 모두 glutamic acid 함량의 감소와 함께 GABA 함량이 증가되는 것이 보고되어(12,34,35), GABA가 glutamic acid로부터 합 성되기 때문에 초기 원료의 glutamic acid 함량 수준과 관련 성이 있음을 보여준다 하겠다. 따라서 품종에 따른 glutamic acid 함량도 발아 시 합성되는 GABA 함량 수준에 영향을 미치는 요인이 될 수 있을 것으로 사료된다.

발아 시간에 따른 발아벼의 유리당 함량 변화 및 당화 특성 발아 시간에 따른 벼의 유리당 함량 변화를 측정한 결과 는 Table 6과 같다. Glucose의 경우 초기 $1.68 \%$ 에서 발아 20 시간 후 약 11 배 증가하였는데, 이후 발아 시간이 길어짐 에 따라 유의적으로 감소하는 경향을 보였다 $(\mathrm{p}<0.05)$. 반면, fructose는 발아 전 검출되지 않았으나 발아 20시간과 28시 간에서 미량 검출되었고, maltose와 sucrose는 발아 전후에 서 모두 검출되지 않았다. Murata 등(36)은 벼 발아 후 4일까 지 sucrose 함량이 일시적으로 감소한 후 발아가 진행됨에 따라 서서히 증가되었다고 보고하였고, $\mathrm{Kim}$ 등(26)은 현미 발아 초기에 sucrose와 glucose와 같은 유리당이 주로 검출 되었으나 발아 시간이 길어질수록 점차 감소하였고, 발아

Table 6. GABA and free sugars contents and saccharification power of unhulled rice germinated at $30^{\circ} \mathrm{C}$ for different time after steeping for $24 \mathrm{~h}$ (dry basis)

\begin{tabular}{cccccccc}
\hline \multirow{2}{*}{ Samples } & \multirow{2}{*}{$\begin{array}{c}\text { GABA content } \\
(\mathrm{mg} / 100 \mathrm{~g})\end{array}$} & Fructose & Glucose & Maltose & Sucrose & Total & $\begin{array}{c}\text { Soluble sugar content of saccharified } \\
\left.\text { soln. }{ }^{2}\right)\end{array}\left(^{\circ}\right.$ Brix $)$ \\
\hline Non-germinated rice & $7.73 \pm 0.21^{\mathrm{d} 1)}$ & - & $1.68 \pm 0.08^{\mathrm{d}}$ & - & - & $1.68 \pm 0.08^{\mathrm{c}}$ & $4.6 \pm 0.2^{\mathrm{c} 2)}$ \\
Germinated rice for $20 \mathrm{~h}$ & $16.28 \pm 0.24^{\mathrm{a}}$ & $0.36 \pm 0.03^{\mathrm{b}}$ & $18.65 \pm 1.19^{\mathrm{a}}$ & - & - & $19.00 \pm 1.20^{\mathrm{a}}$ & $8.8 \pm 0.1^{\mathrm{b}}$ \\
Germinated rice for 24 h & $13.86 \pm 0.91^{\mathrm{b}}$ & - & $17.89 \pm 1.00^{\mathrm{ab}}$ & - & - & $17.89 \pm 1.00^{\mathrm{ab}}$ & $9.7 \pm 0.2^{\mathrm{ab}}$ \\
Germinated rice for 28 h & $9.88 \pm 0.84^{\mathrm{c}}$ & $0.64 \pm 0.04^{\mathrm{a}}$ & $15.93 \pm 0.91^{\mathrm{c}}$ & - & - & $16.57 \pm 0.94^{\mathrm{b}}$ & $10.2 \pm 0.1^{\mathrm{a}}$ \\
Germinated rice for 32 h & $6.17 \pm 0.75^{\mathrm{d}}$ & - & $16.44 \pm 1.06^{\mathrm{bc}}$ & - & - & $16.44 \pm 1.06^{\mathrm{b}}$ & $9.9 \pm 0.3^{\mathrm{a}}$ \\
\hline
\end{tabular}

\footnotetext{
${ }^{1)}$ Values with different small letters in the same column are significantly different by Duncan's multiple range test $(\mathrm{p}<0.05)$. $(\mathrm{a}>\mathrm{b}>\mathrm{c}>\mathrm{d})$.

${ }^{2}$ Saccharified solution was obtained by incubation of germinated rice in water at $45^{\circ} \mathrm{C}$ for $20 \mathrm{~min}$, at $60^{\circ} \mathrm{C}$ for $25 \mathrm{~min}$, at $65^{\circ} \mathrm{C}$ for $80 \mathrm{~min}$, at $72^{\circ} \mathrm{C}$ for $15 \mathrm{~min}$, and at $78^{\circ} \mathrm{C}$ for $5 \mathrm{~min}$.
} 
5 일 후부터는 fructose와 maltose가 검출되기 시작하였다고 보고한 바 있다. 일반적으로 곡류 발아 초기에는 본래 존재 하는 sucrose를 성장 에너지원으로 이용하기 때문에 초기 sucrose 함량은 감소하는 반면, 발아를 위해 a-amylase 활성 이 증가하면서 전분을 분해하여 유리당을 생성하기 때문에 glucose, maltooligosacchride, 및 fructose 등이 형성될 수 있 는 것으로 알려져 있다 $(37,38)$. 이러한 발아 초기에 증가하 다가 감소되는 sucrose와 maltose 변화는 본 연구에서는 관 찰되지 않았는데 이는 본 연구의 경우 발아 시간을 20-32시 간 동안에서만 관찰했기 때문인 것으로 사료된다. 즉, 본 연구에서는 비교적 초엽장 길이가 짧게 분포된 발아 20시 간에서는 glucose 함량이 약 11 배 정도 증가하였고, 초엽장 이 점차 길어지는 발아 28-32시간에서는 유리당의 생성 속도보다 발아를 위해 소비되는 속도가 빨라져 유리당 함량 이 발아 20시간 이후 32 시간까지 지속적으로 감소되었고, 이 기간 동안에서는 sucrose와 maltose는 분해되어 초엽장 의 성장에 이용되었던 것으로 사료된다.

한편, 24 시간 침지 후 $30^{\circ} \mathrm{C}$ 에서 20-32시간 동안 발아시킨 벼의 당화 특성을 조사한 결과는 Table 6 과 같다. 발아 시간 이 길어질수록 발아벼의 당화액 당도는 유의적으로 높아지 는 경향을 나타내어( $\mathrm{p}<0.05), 28$ 시간과 32 시간 동안 발아된 벼에서 가장 높은 당도가 관찰되었는데 이는 약 2.5 배 증가 된 수준으로 약 $10.2{ }^{\circ} \mathrm{Brix}$ 를 나타냈다. 일반적으로 필스너 맥주 제조 시 당화 및 농축공정에서 알코올발효를 위해 요구되는 11-12 ${ }^{\circ} \mathrm{Brix}$ 당액을 얻게 되는데 본 연구에서 제조 된 발아벼를 맥아와 함께 맥주 제조에 이용 시 알코올 생산 에 필요한 충분한 당액 제조가 가능할 것으로 보여진다. 침지 시간이 길어질수록 당화력이 증가되는 현상은 다른 선행 연구에서도 관찰되는데, Lee 등(39)은 현미와 흑미를 상온 $\left(25^{\circ} \mathrm{C}\right)$ 에서 침지 후 각각 $20^{\circ} \mathrm{C}$ 와 $30^{\circ} \mathrm{C}$ 에서 $1-3$ 일 동안 발아시켰을 때 발아 온도가 더 높은 $30^{\circ} \mathrm{C}$ 에서 발아된 시료 에서 당화력이 더 높게 나타났으며 침지 후 발아 시간이 길어질수록 당화력이 증가되었다고 보고하였다. 또한, 2 $55^{\circ} \mathrm{C}$ 에서 4 일간 발아시킨 일품미의 당화력도 발아가 진행되 면서 3배 정도 증가된 것으로 보고되어(27) 벼 품종에 따라 발아 온도와 기간에 따른 생장 속도가 달라지고 이에 따라 효소 당화력도 변화되는 것으로 보인다.

\section{요 약}

본 연구에서는 새일미 품종의 침지 $\left(35^{\circ} \mathrm{C}\right.$ 에서 $8-24$ 시간) 및 발아 $\left(30^{\circ} \mathrm{C}, 20-32\right.$ 시간) 시간에 따른 영양성 및 기능성 성분 변화를 조사하였으며, 필스너 맥주 제조에 이용되는 당화 공정 조건을 적용한 당액을 제조하여 당화 특성을 평가하였다. 침지 및 발아 시간에 따른 발아율은 유의적인 차이가 나타나지 않았으나 침지 및 발아 시간이 길어질수록
초엽장의 길이가 길고 고르게 분포되었다. 발아에 의하여 티아민, 나이아신, 엽산 및 $\mathrm{GABA}$ 함량이 모두 증가하였는 데, 티아민, 나이아신, GABA 함량은 침지 8시간에 최대 함량을 보인 반면, 엽산은 침지 24시간에서 최대 함량을 나타냈다. 한편, 침지 24시간 후 발아된 시료에서는 티아민 과 나이아신 함량은 발아 24시간, 엽산은 발아 32 시간, 그리 고 GABA는 발아 20시간에 최대 함량을 나타내었다. Glucose 함량의 경우 발아에 의해 약 7배 수준까지 증가되 었는데 침지 16 시간에서 가장 높은 함량이 관찰되었으며, 침지 24시간 후에는 발아 20시간에서 최대값을 나타냈다. 발아벼의 당화력은 발아 24시간 조건에서는 침지 시간 16 시간, 침지 24시간 조건에서는 28 시간 발아된 시료에서 가 장 높게 나타났다. 발아 새일미의 당화력, 수용성 비타민, $\mathrm{GABA}$, 발아율 및 초엽장 분포 등을 고려해 볼 때, $35^{\circ} \mathrm{C}$ 에서 24 시간 침지 후 $30^{\circ} \mathrm{C}$ 에서 24-28시간 발아를 통하여 쌀의 영양성 및 기능성 개선과 함께 전분 분해력이 효과적으로 개선될 수 있으므로 맥주 제조 시 맥아 대신 발아벼를 일부 대체하는 경우 당화 공정에 요구되는 당도 생산이 가능할 것으로 보여진다. 다만, 발아에 의한 쌀의 영양성 및 기능성 측면의 극대화를 위해서는 목적하는 성분에 따라 발아 시간 을 조정하는 것이 필요할 것으로 보여진다.

\section{감사의 글}

본 연구는 중소기업청 2015년도 산학연협력 기술개발사 업(No. C0275483) 지원으로 수행된 것으로 이에 감사를 드립니다.

\section{References}

1. Juliano BO (1985) Criteria and tests for rice grain qualities. In: Rice chemistry and technology. Am Assoc Cereal Chem, Inc, St Paul, MN, USA, p 503

2. Seo HI, Kim CS (2011) Pasting properties and gel strength of non-waxy rice flours prepared by heat-moisture treatment. J Korean Soc Food Sci Nutr, 40, 196-204

3. Statistics Korea. http://kostat.go.kr/portal/korea/kor_nw/2/7 $/ 10 /$ index $\cdot$ board? mode $=$ list\&bSeq $=\& a S e q=\& p a g e N o=$ $2 \&$ rowNum $=10 \&$ navCount $=10 \&$ currPg $=\&$ sTarget $=$ title \&sTxt $=$ (accessed January 2017)

4. Kim DC, Choi JW, In MJ (2011) Utilization of Leuconostoc mesenteroides 310-12 strain in the fermentation of a traditional Korean rice-based beverage. J Appl Biol Chem, 54, 21-25 
5. Hwang IG, Yang JW, Kim JY, Yoo SM, Kim GC, Kim JS (2011) Quality characteristics of saccharified rice gruel prepared with different cereal koji. J Korean Soc Food Sci Nutr, 40, 1617-1622

6. Na SJ, Choi SH, Lee SH, Ahn JS, Kim JS (2013) Quality characteristics of Sikhae made with Monascus anka rice. Korean J Culinary Res, 19, 46-56

7. Park JD (2016) Study on processing properties of convenience rice product with different rice. Food Science and Industry, 49, 71-77

8. Oh SK (2016) Development of rice varieties for processing and trend of food industry. Food Industry and Nutrition, 21, 8-14

9. Hyeun SK, Kwon YA, Lee SJ (2012) Quality characteristics of brewed beer with rice adjunct. Food Eng Prog, 16, 139-144

10. Kum JS, Choi BK, Lee HY, Park JD, Park HJ (2004) Physicochemical properties of germinated brown rice. Korean J Food Preserv, 11, 182-188

11. Chun J, Martin JA, Chen L, Lee J, Ye L, Eitenmiller RR (2006) A differential assay of folic acid and total folate in foods containing enriched cereal-grain products to calculate $\mu \mathrm{g}$ dietary folate equivalents ( $\mu \mathrm{g} \mathrm{DFE})$. J Food Compo Anal, 19, 182-187

12. Jo SJ, Hong CO, Yang SY, Choi KK, Kim HK, Yang $\mathrm{H}$, Lee KW (2011) Change in contents of $\gamma$-aminobutyric acid (GABA) and isoflavones in traditional Korean Doenjang by ripening periods. J Korean Soc Food Sci Nutr, 40, 557-564

13. Wilson AM, Work TM, Bushway AA, Bushway RJ (1981) HPLC determination of fructose, glucose, and sucrose in potatoes. J Food Sci, 46, 300-301

14. Cho DH (2010) In vitro digestibility and physicochemical properties of germinated brown rice after hydrothermal treatments. MS Thesis, University of Korea, Korea, p 15-17

15. Palmiano EP, Juliano BO (1972) Biochemical changes in the rice grain during germination. Plant Physiol, 49, 751-756

16. Lee JS (2010) Development of functional germinated brown rice with high GABA content by using GABA synthesis mechanism. Final Report of RDA, 20080401034005

17. Narayan VS, Nair PM (1990) Metabolism, enzymology and possible role of 4-aminobutyrate in higher plants. Phytochemistry, 29, 367-375

18. Omori MT, Tano J, Okamoto T, Tsusshida T, Higuchi
MM (1987) Effect of an aerobically treated tea (gabaron tea) on blood pressure of spontaneously hypertensive rats. Nippon Nigeikagaku Kaishi, 61, 1449-1451

19. Oh SH, Kim SH, Moon YJ, Choi WG (2002) Changes in the levels of $\gamma$-aminobutyric acid and some amino acids by application of glutamic acid solution for the germination of brown rices. Korean J Biotechnol Bioeng, 17, 49-53

20. Zhang H, Yao HY, Chen F, Wang X (2007) Purification and characterization of glutamate decarboxylase from rice germ. Food Chem, 101, 1670-1676

21. Cha JY, Jung HJ, Jeong JJ, Yang HJ, Kim YT, Lee YS (2009) Effects of amino acids on the activities of alcohol metabolizing enzyme alcohol dehydrogenase (ADH) and acetaldehyde dehydrogenase (ALDH). J Life Sci, 19, 1321-1327

22. Jeon GU, Lee HS, Yoon JM, Jang SH, Jung MR, Jeong HS, Lee JS (2010) Effects of heat treatment and selected medicinal plant extracts on GABA content after germination. J Korean Soc Food Sci Nutr, 39, 761-764

23. Kim IS, Kwon TB, Oh SK (1988) Study on the compositional change of free sugars and glucosinolates of rapeseed during germination. Korean J Food Sci Technol, 20, 194-199

24. Aman P (1979) Carbohydrates in raw and germinated seeds from mung bean and chick pea. J Sci Food Agric, 30, 869-875

25. Lee MH, Son HS, Ju JS, Oh SK, Kwon TB (1995) Changes in a-amylase activity and free sugar contents of bluckwheat during germination. Korean J Food Nutr, 8, 32-36

26. Kim SL, Son YK, Son JR, Hur HS (2001) Effect of germination condition and drying methods on physicochemical properties of sprouted brown rice. Korean J Crop Sci, 46, 221-228

27. Kim SS, Lee WJ (1997) Characteristics of germinated rice as a potential raw material for Sikhe production. Korean J Food Sci Technol, 29, 101-106

28. Mo KH, Choi YM, Choi SG, Lee JS (2006) The change of some compounds in brown rice germinated by filtrate of loess suspension. J Agric Life Sci, 40, 41-48

29. Khalil AH, Mansour EH (1995) The effect of cooking, autoclaving and germination on the nutritional quality of faba beans. Food Chem, 54, 177-182

30. Suh HJ, Chung SH, Kim YS, Hong JH, Lee HK (1997) Characteristics of malt prepared with covered barley, naked barley and wheat. J Korean Soc Food Sci Nutr, 
26, 417-421

31. An MK, Ahn JB, Lee SH, Lee KG (2010) Analysis of $\gamma$-aminobutyric acid (GABA) content in germinated pigmented rice. Korean J Food Sci Technol, 42, 632-636

32. Kaur M, Asthir B, Mahajan G (2017) Variation in antioxidants, bioactive compounds and antioxidant capacity in germinated and ungerminated grains of ten rice cultivars. Rice Sci, 24, 349-359

33. Ko JY, Song SB, Lee JS, Kang JR, Seo MC, Oh BG, Kwak DY, Nam MH, Jeong HS, Woo KS (2011) Changes in chemical components of foxtail millet, proso millet, and sorghum with germination. J Korean Soc Food Sci Nutr, 40, 1128-1135

34. Chang JS, Lee BS, Kim YG (1992) Changes in 8 -aminobutyric acid (GABA) and the main constituents by a treatment conditions and of anaerobically treated green tea leaves. Korean J Food Sci Technol, 24, 315-319
35. Tsushida T, Murai T (1987) Conversion of glutamic acid to $\mathrm{\gamma}$-aminobutyric acid in tea leaves under anaerobic conditions. Agric Biol Chem, 51, 2865-2871

36. Murata T, Akazawa T, Fukuchi S (1968) Enzymatic mechanism of starch breakdown in germinating rice seeds: I. An analytical study. J Plant Physiol, 43, 1899-1905

37. Tanaka Y, Ito T, Akazawa T (1970) Enzymic mechanism of starch breakdown in germinating rice seeds: III. a -Amylase isozymes. Plant Physiol, 46, 650-654

38. Lee YT, Seo SJ, Chang HG (1999) Quality characteristics of barley varieties related to enzymatic activity in malt. Korean J Food Sci Technol, 31, 1421-1426

39. Lee HM, Im JS, Park JD, Kum JS, Lee HY, Lee YT (2013) Amylolytic activity of brown rice and black rice during germination. Korean J Food Sci Technol, 45, 333-338 